Article

\title{
Young Farmers' Perceptions about Forest Management for Ecotourism as an Alternative for Development, in Puebla, Mexico
}

\author{
Yésica Mayett-Moreno ${ }^{1}$, Liz Farleidy Villarraga-Flórez ${ }^{2}$ and Sandra Rodríguez-Piñeros ${ }^{3, *}$ \\ 1 Graduate Program, Universidad Popular Autónoma del Estado de Puebla, Puebla 72410, Mexico; \\ yesica.mayett@upaep.mx \\ 2 Programa de Ingeniería Forestal, Universidad Distrital Francisco José de Caldas, Bogotá, Colombia; \\ lizv@udistrital.edu.co \\ 3 Facultad de Zootecnia y Ecología, Universidad Autónoma de Chihuahua, Chihuahua 33820, Mexico \\ * Correspondence: spineros@uach.mx; Tel.: +52-614-434-0363
}

Received: 16 April 2017; Accepted: 21 June 2017; Published: 28 June 2017

\begin{abstract}
The incorporation of young farmers' perceptions about ecotourism is important for decision-making. This was an exploratory and descriptive research project aimed at understanding young farmers' views of a community-based ecotourism (CBE) project. $Q$ methodology was used on a population of young adult farmers, of a small community in the state of Puebla. Three factors reflected their views: There was a group of people who wish to stay in Mexico to pursue the ecotourism project, but lack capabilities. A second group included young farmers who perceive ecotourism as a conservation project, but want to migrate to the United States. The third group was composed of people who envision ecotourism as a source of income for the community's women. The analysis elicited an important inquiry in relation to environmental inter-generation: what kind of development are future generations pursuing?
\end{abstract}

Keywords: local communities; Q methodology; rural development; sustainability

\section{Introduction}

Ecotourism is defined as responsible travel to natural areas, in order to preserve the environment and enhance the quality of life of local communities [1]. Some of the benefits observed from the implementation of ecotourism projects are the protection of forest ecosystems [2] as a source of water [3], wildlife conservation [4], cultural appropriation, and gender equity [5]. In addition, ecotourism has been instrumental for environmental education and consciousness in urban areas, and has also served as a promoter of community participation and preservation of cultural traditions [6,7]. These benefits, along with perceived extra income, seem to be an incentive for small rural communities who desire to improve their quality of life.

According to the United Nations World Tourism Organization, demand for tourism in coastal areas is increasing, impacting strongly on marine ecosystems. Although beaches and archeological sites are the principal tourist attractions of Mexico [8], recent studies have indicated that national tourists showed an increased motivation to visit natural places and magic towns (Magic Town is a project launched by the Mexican government to promote tourism in small towns with unique characteristics, such as important historic events, particular types of food, cultural manifestations, and attractive architecture) [9]. This is of particular importance due to Mexico's large variety of ecosystems, which are rich in species of flora and fauna; they are also home to more than 100 distinct cultures which date back thousands of years. These characteristics, along with ejidos (a form of social organization), could attract national and international tourists who want to learn more about local communities and their interaction with nature. 
Community-based ecotourism (CBE) refers to tourism that is implemented by local groups, who have control over the design, development, management, and distribution of benefits, of the activities associated with ecotourism, with the final objective being to enhance their quality of life and preserve ecosystems [10]. In this sense, CBE could offer economic, social, and ecological benefits, and serve as a model of sustainable rural development [11] to alleviate poverty [12], particularly in rural communities with well-established social capital. CBE has also been considered an instrument to change environmental attitudes and behavior, as a result of cognitive components of social capital such as organization, social trust and reciprocity that grow around a project of common well-being [13-16].

Despite all the benefits provided by CBE, there is little evidence of the basic capabilities that local people need to undertake to implement such projects [17]. However, evidence from around the world suggests that CBE could bring success or failure. Das and Chatterjee [18] argued that most ecotourism projects are imposed on communities without listening to their opinions; this results in conflicts, jeopardizing the success of the projects. For this reason, knowing the plurality of opinions in a community directly involved in a CBE project is important [19]: it helps to reduce conflict, promote community participation, and provide guidance as to how to better implement projects [20-22].

The objective of this study was to identify how young adults (children of a forest's owners) from a small community of Puebla, Mexico, perceive an ecotourism project that their parents established in 2009. In addition, the study also aimed to explore young people's perceptions of their capacity to undertake the CBE project. The findings of the study serve to inform national and local development agencies: to address their efforts to understand people's desires, expectations and capabilities, and to enhance the acceptability and make more effective the implementation of development projects.

\section{Literature Review}

\section{Ecotourism, Community Participation, and Social Values}

The debate on the effects of development (that only benefit the few) on natural capital's deterioration (that directly impact rural communities) remains an issue at the national and international level. While this issue most probably will not be solved in the near future, several strategies have been implemented to favor rural development while conserving the remaining natural environments. Ecotourism arose as an alternative that provides economic, social, and environmental benefits to the rural poor [23-25]; however, due to its rapid expansion, those benefits do not directly reach the local population [26]. Therefore, several scholars have agreed that local participation in the implementation of ecotourism projects would lead to success $[2,27,28]$, due to its ability to enhance community cohesion and commitments to conservation $[29,30]$.

Kontogeorgopoulos [31] argued that participation per se does not guarantee success in implementing CBE. There are several factors that may hinder CBE projects, such as the limited employment that it could bring, the low economic incentives compared with the high investment [32], land insecurity [33], social conflict [14], and gender inequality [34]. Slow development in rural areas has forced people, in particular young males, to migrate to urban areas, or to more industrialized countries [35]. This situation in turn leads to several problems which affect both rural and urban societies, such as fast growing urban populations living in slums, migrants working in underpaid, unstable jobs [36], and, most commonly, the feminization of agriculture [37]. Although women have played an important role in subsistence agriculture [38], they face several challenges that are aggravated by the negative effects of climate change, which could increase rural poverty. Some of those challenges are associated with lack of empowerment, capabilities, and low participation in decision making [39] which varies between regions and ethnic groups. In this sense, ecotourism offers opportunities for women to be involved, and to create social capital and gender empowerment [40]. It would also serve as a strategy to compensate for those benefits that are lost when women are not able to carry out labor-intensive farm work. However, ecotourism per se is not the only answer to women's empowerment: young farmers are more open to accepting the role of women in agriculture [41] as 
a result of the current agricultural transition [38], which has its roots in the fall of rural work force since the past decade [42], and increasing access to education in rural areas.

Understanding young farmers' view, believes and values in the context of CBE is important to strengthen social institutions and to encourage pro-environmental behaviors [43]; it also helps to planning and to frame policy [19,43]. Hicks et al [44] argued that values, as part of a social dimension are of extreme importance to achieve sustainability and to avoid social discontent, since people would reject polices that are not consisted with their values and needs.

\section{Materials and Methods}

\subsection{Study Site}

In 2009, owners of forested land in La Preciosita, a small rural community in the state of Puebla, Mexico, unanimously decided to pursue forest management for ecotourism. They wanted to implement a project in which tourists would visit the forest reserve and spend the night(s) at the community's residents' houses, where they would provide food, and learn about community traditions. This initiative was further named as the "ecotourism project of La Preciosita". Among the objectives mentioned before, its underlying goal was to provide jobs for the young adult population of the community who were migrating to the US or Mexico City, leaving agricultural practices under the care of women and elders. According to forest owners' rules, everyone can benefit from ecotourism but only forest owners can decide what can be done in the forest, which is the main attraction for tourists. Six years after the implementation of the project, a large number of young adults came back to town looking to pursue the project and reestablish their lives on their parents' or grand parents' land. Figure 1 shows the geographic location of the small town.

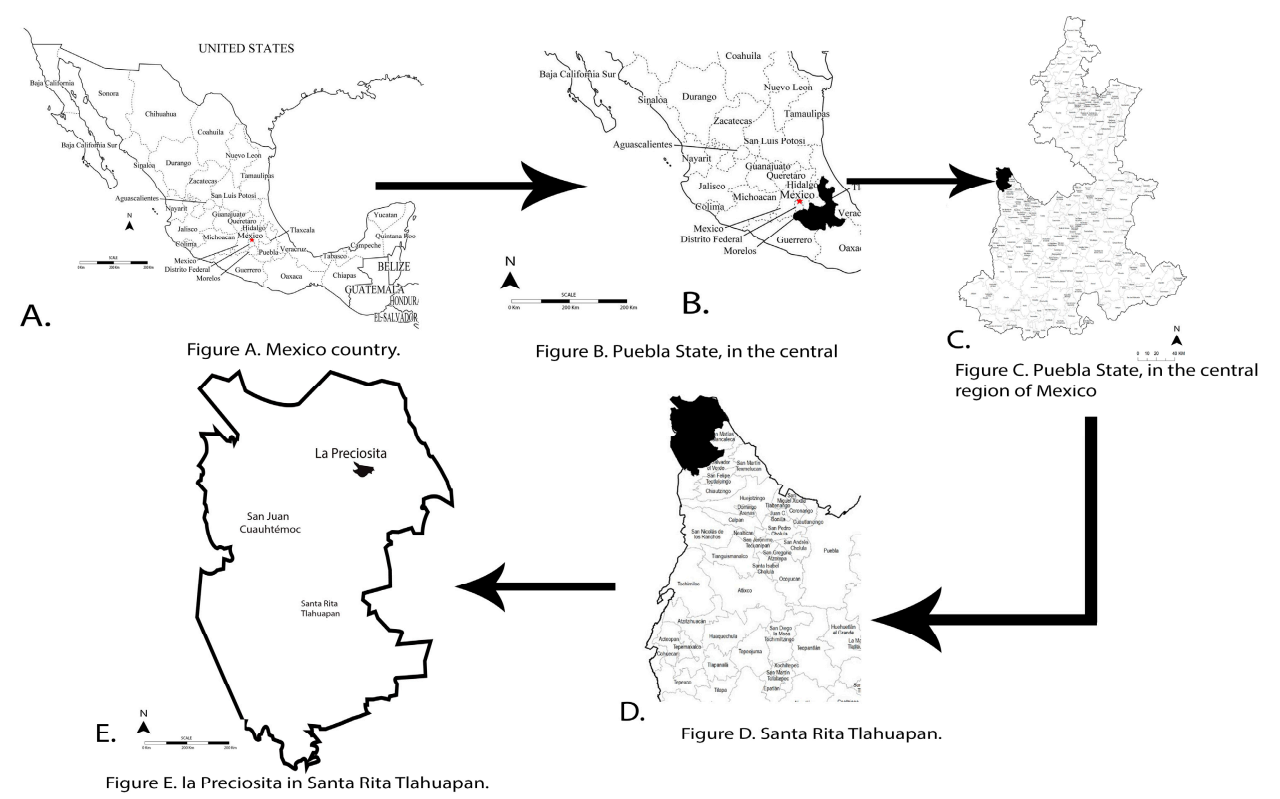

Figure 1. Location of study site.

\subsection{Instrumentation}

To understand young adults' perception of CBE, we used Q methodology, which has been used to identify groups of people who share common views [45]. This methodology helps to systematically study subjectivity: knowing that individuals are aware of their values, motivations, and beliefs, they can communicate them to make informed decisions. For this reason, the methodology places more emphasis on what people say, rather than on participants' demographics. What people say reflects their opinions and values [46]. Thus, a good selection of participants is of great importance-a 
small number of participants with well-formed ideas about an issue is usually enough [47]. Typically, the number of opinions or statements are greater than the number of participants; although there are several $Q$ studies that used fewer statements than participants, Webler and Tuler [48] proposed a number of opinions (statements) around 32 and 40. A thorough description and theoretical foundation of the procedure can be found in Bruce and McKeown [49]. For the purposes of this paper, only a brief description is provided.

Q methodology is performed in three stages: the development of the instrument which is known as Q-sample, data collection known as Q-sorting, and data analysis. The development of the Q-sample includes the construction of the concourse, which is the universe of ideas of a topic. It could be built with information directly collected from the population under study through in-depth interviews, narratives, meeting minutes, press reports, or previous studies in the same area. The most common way to select the Q-sample is by classifying all the statements of the concourse in groups of dimensions related to the topic of the study, followed by a content analysis. Selected statements should be different among them, since the purpose is to have a wide variety of opinions about a topic. Then, the Q-sample is composed of the most representative statements. Some studies use external data, such standardized scales, studies in other populations, or related interviews to directly construct the Q-sample. The data collection stage comprises participant selection (P-set) and statement sorting (Q-sorts). For the P-set, it is recommended to select a group of individuals with strong and diverse opinions about the topic under study. Then, each participant of the P-set organizes the statements of the Q-sample in a grid that has a pre-determined quasi-normal distribution, assigning a subjective value to each statement and thus, revealing their point of view or personal preferences [31]. Each of these arrangements takes the name of the Q-sort, which are the base for statistical analysis.

Q-sorts are analyzed in software PQ-Method ${ }^{\circledR} 2006$ (developed by John Atkinson at Kent State University, Kent, OH, USA, and maintained by Peter Schmolck), which uses the factor analysis procedure to extract factors. Thus, people with the same point of view will share the same factor. Factor interpretation is based on the factor score for each statement, which is the normalized weighted average or Z-score of respondents that define the factor [50].

For this study, we built the concourse from face-to-face semi-structured interviews with a group of 12 young adults who participated in a workshop on community development, and five key participants (a group composed of both the forest's owners and children of forest owners, who were in charge of the CBE project for the period 2013-2016). The interview aimed to capture opinions about the progress of the project, and how they have benefitted or not from it. It also asked for the challenges, advantages and disadvantages to implementing the project; in addition, we used standardized instruments and studies related to the topic $[2,8,51-53]$. To select a wide range of young adults' opinions about the ecotourism project and its implementation, a content analysis was performed resulting in 36 statements that comprised the Q-sample.

In a community meeting, we purposefully selected 16 forest owners' children above 18 years old (five women and 11 men), who expressed strong opinions about the future of the community and who recently had come back from the US. Participants sorted the statements in a predetermined bell-shaped figure (Figure 2), giving them a ranking from -5 to 5 , under the condition of the statement: "how do you identify yourself with the ecotourism project and the forest management plan for it?"

Finally, all 16 sorts were analyzed in PQ-Method ${ }^{\circledR} 2000$ software (developed by John Atkinson at Kent State University, Kent, OH, USA, and maintained by Peter Schmolck), which intercorrelated numeric data of each participant's sort with the sorts of all the other participants to obtain a correlation matrix for further factor analysis to identify groups of people who share similar opinions. 


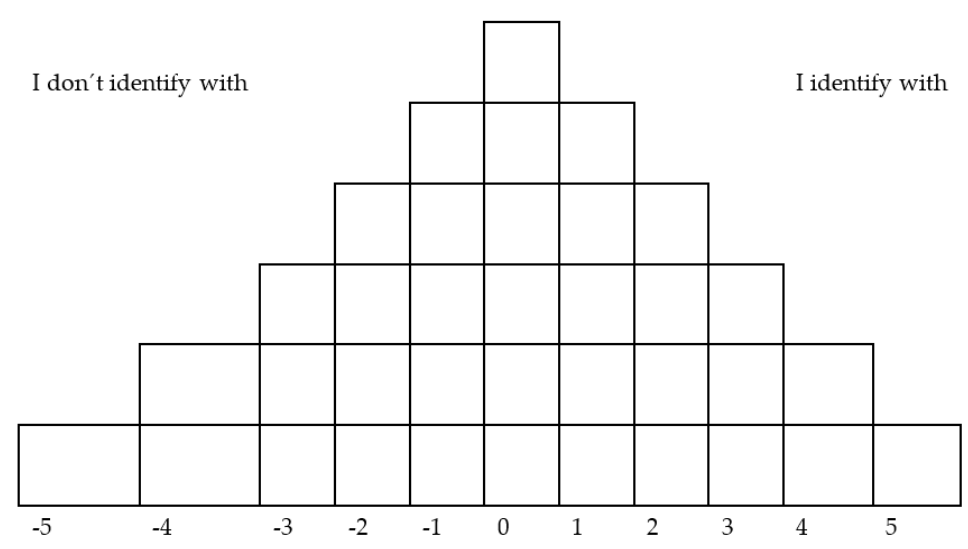

Figure 2. Predetermined array for the statements.

\section{Results}

Principal component analysis of the sorts was performed followed by a Varimax rotation to extract three factors. The number of factors extracted was based on the eigen value and their contribution to explaining the variance. Sorts that exceed a factor loading of 0.548 were considered significant for its factor at $p<0.001(=3.29 / \sqrt{ } \mathrm{N}$ where $\mathrm{N}=$ number of statements), meaning that those sorts highly represented the factor. Out of the 16 sorts, 14 loaded above 0.548 in one and only one factor, making them pure sorts (Table 1). In Q methodology, a factor that has at least two Q sorts that significantly load in it is considered relevant for the study.

Table 1. Factors' loadings.

\begin{tabular}{cccc}
\hline Sort & Factor I & Factor II & Factor III \\
\hline 1 & 0.322 & $0.647 \mathrm{X}$ & 0.239 \\
2 & $0.744 \mathrm{X}$ & -0.027 & 0.026 \\
3 & $0.617 \mathrm{X}$ & 0.534 & -0.206 \\
4 & -0.090 & $0.601 \mathrm{X}$ & 0.076 \\
5 & $0.576 \mathrm{X}$ & 0.003 & 0.395 \\
6 & $0.689 \mathrm{X}$ & 0.144 & 0.244 \\
7 & 0.510 & 0.224 & $0.616 \mathrm{X}$ \\
8 & 0.106 & 0.089 & $0.646 \mathrm{X}$ \\
9 & 0.442 & 0.111 & 0.447 \\
10 & $0.724 \mathrm{X}$ & 0.275 & 0.378 \\
11 & 0.219 & 0.156 & $0.814 \mathrm{X}$ \\
12 & $0.683 \mathrm{X}$ & 0.170 & 0.311 \\
13 & 0.379 & $0.665 \mathrm{X}$ & 0.036 \\
14 & -0.111 & $0.631 \mathrm{X}$ & 0.277 \\
15 & 0.300 & $0.654 \mathrm{X}$ & 0.035 \\
16 & 0.104 & 0.513 & 0.475 \\
\hline
\end{tabular}

$\mathrm{X}=$ significant sort.

Factor interpretation is based on the values of $Z$ (Table 2) for each statement, statements that distinguished among factors, and those that were placed on the extremes of the grid. Then, a coherent narrative is described for each factor, indicating the views of people who load significantly in that factor. 
Table 2. Factors' loadings.

\begin{tabular}{|c|c|c|c|c|}
\hline \multirow{2}{*}{$\#$} & \multirow{2}{*}{ Statements } & \multicolumn{3}{|c|}{ Factors } \\
\hline & & I & II & III \\
\hline 1 & I agree to manage the forest for ecotourism & 1.85 & $-0.08 *$ & 1.97 \\
\hline 2 & The priority is to preserve the forest for ecotourism & $1.97 *$ & 0.66 & 0.73 \\
\hline 3 & $\begin{array}{l}\text { The reserve needs to be cleaned so it can look good, extract trees that } \\
\text { are not healthy }\end{array}$ & 0.55 & 0.62 & 1.02 \\
\hline 4 & $\begin{array}{l}\text { I want the ecotourism to be a source of income to me and my family in } \\
\text { the future }\end{array}$ & 1.67 & 1.09 & 1.46 \\
\hline 5 & I would rather work in ecotourism than agriculture & -0.85 & -1.09 & -0.61 \\
\hline 6 & Agriculture is not profitable & -0.06 & -0.75 & -0.81 \\
\hline 7 & Agriculture demands too much physical work & -0.81 & -0.39 & -1.53 \\
\hline 8 & $\begin{array}{l}\text { With income from ecotourism, I would buy food, so I will not have } \\
\text { to farm }\end{array}$ & -0.63 & -1 & -0.67 \\
\hline 9 & I want to use my ejido land for other activities & $-1.72 *$ & 0.55 & $-0.5^{*}$ \\
\hline 10 & $\begin{array}{l}\text { I think that the young population can implement the ecotourism Project } \\
\text { successfully }\end{array}$ & -0.09 & -0.76 & $1.19^{*}$ \\
\hline 11 & $\begin{array}{l}\text { I think that the young population of the community is more united } \\
\text { than our parents }\end{array}$ & -1.39 & $0.04 *$ & -0.97 \\
\hline 12 & $\begin{array}{l}\text { I think that communication among the young population is the most } \\
\text { important factor }\end{array}$ & -0.06 & 0.5 & 0.51 \\
\hline 13 & I want to stay in Mexico to go to school and help my community & 1.19 & $-0.49 *$ & 0.41 \\
\hline 14 & $\begin{array}{l}\text { I believe that if our parents authorized it, we (the young population) } \\
\text { could undertake the ecotourism project }\end{array}$ & -0.15 & 0.03 & 0.16 \\
\hline 15 & I am trained to farm but not in ecotourism & -0.9 & 0.14 & -0.47 \\
\hline 16 & I am trained in ecotourism but not to farm & -0.78 & -1.4 & -0.69 \\
\hline 17 & Ecotourism is a way to conserve the forest & $0.05 *$ & 1.76 & 1.14 \\
\hline 18 & I want to receive training to manage the ecotourism project & 1.21 & 0.65 & $-1.02 *$ \\
\hline 19 & High school is enough to manage the ecotourism project & $-1.4 *$ & -0.14 & -0.32 \\
\hline 20 & University education is important to manage the ecotourism project & -1.13 & -1.44 & -0.92 \\
\hline 21 & I would invest my time in the ecotourism project & 0.3 & 0.32 & -0.47 \\
\hline 22 & I am sure that there are enough visitors for the ecotourism project & 0.06 & -0.29 & 0.36 \\
\hline 23 & I think that several people are visiting the reserve and they like it & -1.01 & -1.16 & -0.81 \\
\hline 24 & The reserve administration should include women & 0.15 & $-0.67^{*}$ & 0.63 \\
\hline 25 & Ecotourism is a way to keep our culture & 0.42 & $1.76^{*}$ & 0.12 \\
\hline 26 & Ecotourism is a good opportunity for women to obtain income & 0.24 & 0.87 & 1.29 \\
\hline 27 & I think that visitors need to be limited & $-0.28 *$ & $-1.66^{*}$ & $1.12 *$ \\
\hline 28 & I would like tourists to learn about the plants and animals of the reserve & 0.77 & 1.25 & 1.27 \\
\hline 29 & I would like the reserve to be signposted and have a trail & 0.44 & $1.8 *$ & 0.5 \\
\hline 30 & I would like the reserve to have a camping place & 0.92 & 1.15 & 0.76 \\
\hline 31 & I would like the reserve to have a lookout point over the landscape & 0.89 & 1.46 & $0.02 *$ \\
\hline 32 & $\begin{array}{l}\text { I would like the reserve to have hammocks and swings for visitors } \\
\text { to enjoy }\end{array}$ & 1.29 & 0.57 & 0.8 \\
\hline 33 & I think that tourists should not enter sacred places inside the reserve & $-2.11 *$ & -1.09 & -0.67 \\
\hline 34 & Ecotourism would bring enough jobs to quit farming & $0.14 *$ & $-0.76^{*}$ & $-1.7^{*}$ \\
\hline 35 & $\begin{array}{l}\text { I would not go to the reserve, but I want to accommodate tourists in } \\
\text { my house }\end{array}$ & -0.55 & -1.14 & -1.23 \\
\hline 36 & Ecotourism is less physically demanding than farming & -0.23 & -0.91 & $-2.07^{*}$ \\
\hline
\end{tabular}




\subsection{Factor I. Pro Ecotourism and Empowerment}

This factor is defined by six participants (two women and four men). The most relevant opinion is that they would like to continue the ecotourism project started by their parents a few years ago (statement 1); therefore, preserving the forest is important (statement 2). They see the project as a source of income for their families (statement 4); in this regard, they are willing to invest time in training. This group of young adults agrees that university education is important to the success of the project; they want to stay in Mexico to help with the development of the community and they are also willing to enhance forest areas to receive visitors; limiting entrance to sacred places is not considered by this group (statements 13, 18, 32 and 33). Although there is an open interest to accept the project as their parents envisioned, this group is not sure whether their parents will allow them to be involved (statement 14). They also have some doubts on how ecotourism will provide enough jobs for them to abandon agriculture practices, in which they are not well trained (22, 34 and 16), and how the forest would be preserved (statement 17). This group does not want to use their ejido land for other activities than agriculture.

\subsection{Factor II. Pro Conservation and Income for Women}

Five people (four men) load significantly in this factor. They have a strong opinion on ecotourism as a double-folded activity that will support forest conservation and cultural pride (statements 17 and 25). They may consider using their ejido land for ecotourism (statement 9). This group also perceives ecotourism as a source of jobs for women (statement 26). They would enhance the "infrastructure" of the forest to include a camp site, lookout point, and places for wildlife watching (statements 29, 28, 30 and 31). Although they are willing to cooperate with the development of the reserve, they recognize that they have little knowledge on how to manage the reserve and do not want to work in ecotourism (statements 16 and 5). This group believes that there will be not enough jobs since there are few visitors (statements 23 and 34); therefore, they do not want to restrict the number of visitors (statement 27). They also think that the income from ecotourism will not contribute to food security, in terms of buying food (statement 8). Although this group perceives the ecotourism project as positive, it seems that they do not want to be in charge of it, since it is a project for women while they are out of town (statement 13).

\subsection{Factor III. Ecotourism as a Project for the Young Population of the Community}

This factor was defined by three men. Although they have similar views to people from factor I who agree to manage the reserve for ecotourism as a source of income for their families (statements 1 and 4), the difference relies on the fact that they have great confidence that the young population, in particular women (statement 26), can undertake the project successfully (statement 10). However, they think that the reserve needs some management to receive visitors (statement 3 ). They acknowledge their lack of organization (statement 11) and believe that they have the abilities to carry out the project (statement 18). This group is concerned about the number of visitors and they think that a limit should be established. They will add hammocks and a camp site for visitors. Similar to the other two groups, they know that the jobs will be limited; therefore, they do not have much interest in receiving some training. In addition, they considered agricultural practices as profitable and will not dedicate their land to other uses.

In addition, consensus statements (Table 3) provided important information for the analysis of data. Consensus statements are those that load significantly for all participants in the three factors. In this regard, this information is significant for policy making. A graphical representation for each factor is shown in Figure 3, indicating that if we grouped people who loaded significantly in each factor, and asked them to organize the statements, each group would organize statements in that way. 


\begin{tabular}{|c|c|c|c|c|c|c|c|c|c|c|}
\hline & & & & cotur & and & ower & & & & \\
\hline Idon't & ntify & & & & 6 & & & & Iidentify w & \\
\hline & & 11 & 7 & 27 & 17 & 25 & 28 & 13 & & \\
\hline & 9 & 20 & 15 & 35 & 22 & 26 & 30 & 18 & 1 & \\
\hline 33 & 19 & 23 & 16 & 36 & 34 & 29 & 31 & 32 & 4 & 2 \\
\hline-5 & -4 & -3 & -2 & -1 & 0 & 1 & 2 & 3 & 4 & 5 \\
\hline
\end{tabular}

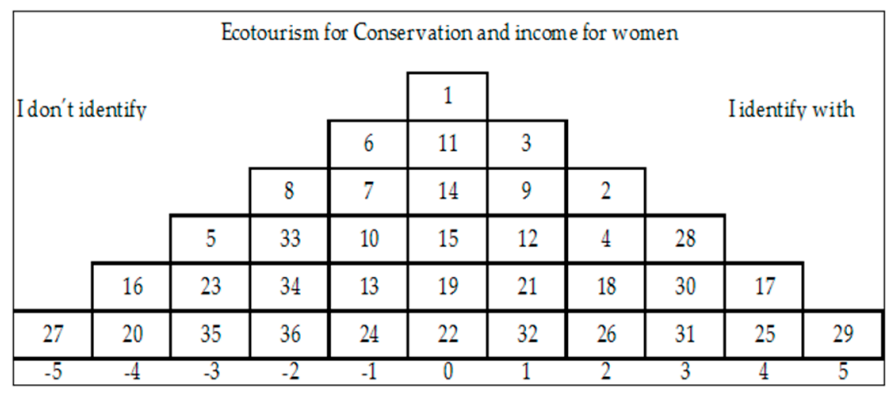

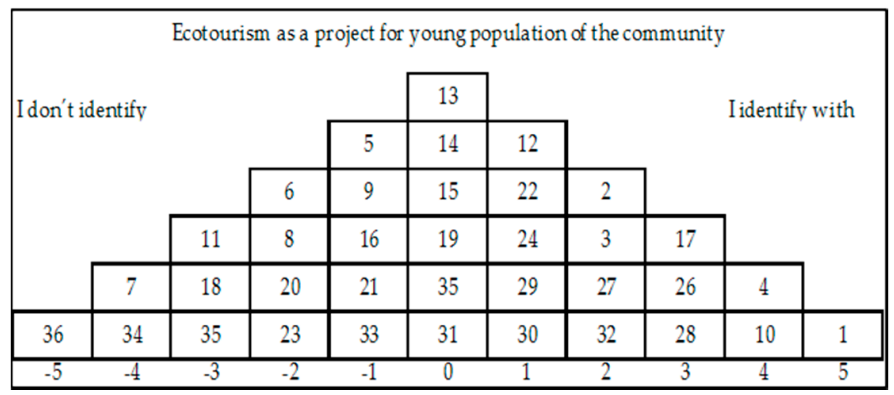

Figure 3. Representation of factors.

Table 3. Consensus statements.

\begin{tabular}{|c|c|c|c|c|}
\hline \multirow{2}{*}{ \# } & \multirow{2}{*}{ Statements } & \multicolumn{3}{|c|}{ Factors } \\
\hline & & $\mathbf{I}$ & II & III \\
\hline $3 *$ & $\begin{array}{l}\text { The reserve needs to be cleaned to improve its appearance. Extract trees that } \\
\text { are not healthy }\end{array}$ & 0.55 & 0.62 & 1.02 \\
\hline 4 & I want ecotourism to be a source of income for me and my family in the future & 1.67 & 1.09 & 1.46 \\
\hline $5 *$ & I would rather work in ecotourism than agriculture & -0.85 & -1.09 & -0.61 \\
\hline 6 & Agriculture is not profitable & -0.06 & -0.75 & -0.81 \\
\hline $8^{*}$ & With the income from ecotourism, I would buy food. I will not have to farm & -0.63 & -1 & -0.67 \\
\hline $12 *$ & $\begin{array}{l}\text { I think that communication among the young population is the most } \\
\text { important factor }\end{array}$ & -0.06 & 0.5 & 0.51 \\
\hline $14^{*}$ & $\begin{array}{l}\text { I believe that if our parents authorized it, we (the young population) could } \\
\text { undertake the ecotourism project }\end{array}$ & -0.15 & 0.03 & 0.16 \\
\hline 16 & I am trained in ecotourism but not to farm & -0.78 & -1.4 & -0.69 \\
\hline $20 *$ & University education is important to manage the ecotourism project & -1.13 & -1.44 & -0.92 \\
\hline 21 & I would invest my time in the ecotourism project & 0.3 & 0.32 & -0.47 \\
\hline 22 & I am sure that there are enough visitors for the ecotourism project & 0.06 & -0.29 & 0.36 \\
\hline $23 *$ & I think that several people are visiting the reserve and they like it & -1.01 & -1.16 & -0.81 \\
\hline $28 *$ & I would like tourists to learn about the plants and animals of the reserve & 0.77 & 1.25 & 1.27 \\
\hline
\end{tabular}


Table 3. Cont.

\begin{tabular}{clccc}
\hline \multirow{2}{*}{$\#$} & Statements & \multicolumn{2}{c}{ Factors } \\
\cline { 3 - 5 } & & I & II & III \\
\hline $30 *$ & I would like the reserve to have a camp site & 0.92 & 1.15 & 0.76 \\
\hline 32 & I would like the reserve to have hammocks and swings for visitor to enjoy & 1.29 & 0.57 & 0.8 \\
\hline 35 & I would not go to the reserve, but I want to accommodate tourists in my house & -0.55 & -1.14 & -1.23 \\
\hline & $*$ e distinguished statement at $p<0.01$. & &
\end{tabular}

In general, the group of young adults acknowledges the importance of enhancing the health and infrastructure of the reserve to be able to offer good service to visitors, because there are not enough visitors. In addition, it is clear that they prefer to work on agriculture since they perceived it as being profitable, and income from ecotourism would not be enough to buy food. Participants also agreed that university education is not important to manage the activities related to ecotourism. Finally, they believe that they need to communicate more often and also obtain the authorization of their parents to undertake the project.

\section{Discussion}

Currently, there is an agreement on the wide variety of economic, social, and environmental benefits of ecotourism. There are different ways in which to value those benefits; however, when including the plurality of values of the population they would serve, planning and implementation becomes a complex task. The inclusion of social values in policy decisions would legitimize a participatory process that could eventually be reflected in environmental sustainability [54]. Due to the fact that stakeholders of ecotourism projects should assume roles and responsibilities for the sustainability of the resources [55], it is of great importance to understand how they value their resources, beyond the economic term.

Young adults of the community will eventually inherit the forest and the projects associated with it. Although ecotourism is not considered a good source of steady income, it is perceived as a source of jobs for women which could generate extra income. Although $Q$ methodology does not allow for generalization, this study demonstrated the importance of including perceptions, and it calls for more research on the role of women in rural areas, since many rural areas around the world are inhabited principally by women. This is due to male outmigration and wars, leading to the feminization of agriculture [56]. This issue has important economic implications in states with high levels of rural poverty, food insecurity, and unstable land tenure in particular for women of some ejidos and indigenous communities who are not entitled to hold a property right [57]. This therefore implies the need to rethink how policies will foster rural aid, to enhance livelihood an empower women [36].

According to the study, the participants of Factor II stated their intension to leave Mexico to look for opportunities. This perception contrasted the perception of their parents who started the project to bring back their children. Meanwhile, the group of young adults who want to stay in Mexico want to pursue the project, but lack the capabilities to undertake it, and also lack capabilities to farm their lands. According to consensus statements, young farmers of this community do not see university education as being important to develop their projects. This raises several questions about the sustainability and intergenerationality of rural environmental projects: Do we really know what is the type of development that current generations envision for their short- and long-term future? Are they prepared/ready to undertake new projects and do they want to receive training? It would be important to consider these questions before designing rural projects, and most importantly if the future of the rural areas is uncertain, due to large population increases in urban areas [56]. In addition, it seems that social linkages, as an important component to foster projects [58,59], are still incipient among new generations, and this is mainly due to outmigration. 
Young adults perceived the ecotourism project as an alternative to obtain income, but not as a steady source of it. They also agreed to preserve the forest and revealed their willingness to help in its conservation, although they did not foresee themselves working on it. Similar to their parents, they perceived the conservation of the forest as a symbol of community pride. This result is consistent with previous studies that have shown how communities organized themselves to promote conservation and cultural diversity [60,61].

This study also unveiled that there is a group of young adults who want to leave their lands due to a lack of capabilities and the perceived low income from ecotourism, suggesting that it would be necessary to find alternatives that complement the temporary job that ecotourism may provide them. As opposed to their parents, who preferred social cohesion above income generation, this new generation of young adults is willing to leave their lands to make money to support their families.

Understanding young adults' perceptions is important to policy making and intervention. The establishment of the projects was successful due to forest owners' desire to bring their children back; however, the continuation of the project is at risk if the future stakeholders are not empowered and not trained. Although this was a case study, the methodology could apply to other places in which community values need to be involved. Further research on young farmers' expectations and desires is needed, as new technology and increasing education have changed the way people think about rural areas.

Managerial training is important in this community: young adults need to understand how to enhance their project as a business that could grow, thus demonstrating the benefits of keeping the forest for conservation. Training in customer services and advertising would also be desirable: some of the young adults have worked in the US in restaurants, meaning that they understand the importance of keeping the customers satisfied and providing good service.

\section{Conclusions}

Community-based ecotourism as a strategy for development is possible. For it to be successful, it is important to know stakeholders' opinions, perceptions and what they expect from the project, so that they can be included in planning and decision making. This is the third study of an effort that sought to help the community to plan a project for ecotourism. The previous two studies explored forest owners' perceptions and desires about ecotourism. Results of those studies showed that forest owners want to implement an ecotourism project as a source of income and jobs to encourage their children, who are young adults, to come back from the US; evidently, family cohesion is important to them. This third study revealed young adults' perceptions about that project. Social values and forest conservation are two strong and similar opinions in both groups (forest owners and forest owners' children); however, in terms of income and jobs, both groups have different opinions.

Knowing young adults' perceptions is important in any kind of natural resource project. Most of the projects associated with reforestation and conservation are long term; therefore, they need some sort of certainty regarding who will undertake future development and monitoring progress. There are some examples of projects that empower young people to undertake their parents' projects, and that can be replicated or adapted in other countries or regions. In the US, for example, the 4- $\mathrm{H}$, as an extension strategy, provides training to young people who plan to become farmers, ranchers, and foresters.

Acknowledgments: Authors thanks the Program "Apuesta al Futuro" of the Universidad Popular Autónoma del Estado de Puebla UPAEP, for helping us to establish communication with the young population of the community. We are also thankful to all the members of the community for their warm welcome and willingness to contribute to this study.

Author Contributions: Yésica Mayett-Moreno and Sandra Rodríguez-Piñeros conceived, designed, collected and analyzed data; Liz Farleidy Villarraga-Flórez helped with data analysis and edition.

Conflicts of Interest: The authors declare no conflict of interest. 


\section{References}

1. The International Ecotourism Society (TIES). The Definition. Available online: www.ecotourism.org/whatis-ecotourism (accessed on 10 March 2016 ).

2. Stem, C.J.; Lassoie, J.P.; Lee, D.R.; Deshler, D.D.; Schelhas, J.W. Community participation in ecotourism benefits: The link to conservation practices and perspectives. Soc. Nat. Resour. 2003, 16, 387-413. [CrossRef]

3. Brancalion, P.H.; Cardozo, I.V.; Camatta, A.; Aronson, J.; Rodrigues, R.R. Cultural ecosystem services and popular perceptions of the benefits of an ecological restoration project in the Brazilian Atlantic forest. Restor. Ecol. 2014, 22, 65-71. [CrossRef]

4. Koechlin, J.; Inkaterra, G.; Inkaterra, O.D.; Inka, T.A.; Schmitt, A. Ecosystem Restoration and Conservation in the Machu Picchu Cloud Forest through Ecotourism. In Private-Sector Experiences in Land Reclamation and Ecosystem Recovery Restoring Life on Earth; Technical Series No. 88; Mulongoy, M.J., John, F., Eds.; Secretariat of the Convention on Biological Diversity: Montreal, QC, Canada, 2016; p. 129.

5. Turner, K.L.; Berkes, F.; Turner, N.J. Indigenous perspectives on ecotourism development: A British Columbia case study. J. Enterp. Commun. People Places Glob. Econ. 2012, 6, 213-229. [CrossRef]

6. Walter, P.G.; Reimer, J.K. The "ecotourism curriculum" and visitor learning in community-based ecotourism: Case studies from Thailand and Cambodia. Pac. J. Tour. Res. 2012, 17, 213-229. [CrossRef]

7. Sakata, H.; Prideaux, B. An alternative approach to community-based ecotourism: A bottom-up locally initiated non-monetised project in Papua New Guinea. J. Sustain. Tour. 2013, 21, 880-899. [CrossRef]

8. Yanza, E.A. Diseño de un modelo de desarrollo ecoturístico comunitario en la zona rural de Coroneo, sur de Guanajuato. Rev. Electrón. Divulg. Investig. 2012, 3, 1-26.

9. Figueroa-González, L.F.; Cavazos-Arroyo, J.; Mayett-Moreno, Y. Desarrollo de productos turísticos rurales sustentables. Propuesta y validación de expertos respecto a tres variables. Periplo Sustent. 2015, 28, 115-139.

10. Scheyvens, R. Ecotourism and the empowerment of local communities. Tour. Manag. Perspect. 1999, 20, 245-249. [CrossRef]

11. Wunder, S. Ecotourism and economic incentives-An empirical approach. Ecol. Econ. 2000, 32, 465-479. [CrossRef]

12. Manu, I.; Kuuder, C.J.W. Community-based ecotourism and livelihood enhancement in Sirigu, Ghana. Int. J. Hum. Soc. Sci. 2012, 2, 97.

13. Harpham, T.; Grant, E.; Thomas, E. Measuring social capital within health surveys: Key issues. Health Policy Plan. 2002, 17, 106-111. [CrossRef] [PubMed]

14. Stronza, A.; Gordillo, J. Community views of ecotourism. Ann. Tour. Res. 2008, 2, 448-468. [CrossRef]

15. Prior, T.; Eriksen, C. Wildfire preparedness, community cohesion and social-ecological systems. Glob. Environ. Chang. 2013, 23, 1575-1586. [CrossRef]

16. Liu, J.; Qu, H.; Huang, D.; Chen, G.; Yue, X.; Zhao, X.; Liang, Z. The role of social capital in encouraging residents' pro-environmental behaviors in community-based ecotourism. Tour. Manag. Perspect. 2014, 41, 19-201. [CrossRef]

17. Zapata, M.J.; Hall, C.M.; Lindo, P.; Vanderschaeghe, M. Can community-based tourism contribute to development and poverty alleviation? Lessons from Nicaragua. Curr. Issues Tour. 2011, 14, 725. [CrossRef]

18. Das, M.; Chatterjee, B. Ecotourism: A panacea or a predicament? Tour. Manag. Perspect. 2015, 14, 3-16. [CrossRef]

19. Rodriguez-Piñeros, S.; Focht, W.; Lewis, D.K.; Montgomery, D. Incorporating values into community-scale sustainable forest management plans: An application of Q methodology. Small Scale For. 2012, 11, 167-183. [CrossRef]

20. Wilkinson, P.; Pratiwi, W. Gender and tourism in an Indonesian village. Ann. Tour. Res. 1995, 22, $283-299$. [CrossRef]

21. Reed, M.S. Stakeholder participation for environmental management: A literature review. Biol. Conserv. 2008, 141, 2417-2431. [CrossRef]

22. Habibah, A.I.; Mushrifah, J.; Hamzah, M.E.; Toriman, A.; Buang, K.; Jusoff, M.J.; Mohd Fuad, A.C.E.; Azima, A.M.A.H. Assessing Natural Capitals for Sustainable Ecotourism in Tasik Chini Biosphere Reserve. Adv. Nat. Appl. Sci. 2012, 6, 1-9.

23. Agrawal, A.; Redford, K. Poverty, Development, and Biodiversity Conservation: Shooting in the Dark? Working Paper No. 26; Wildlife Conservation Society: New York, NY, USA, 2006. 
24. Hunter, W.C. Performing culture at indigenous culture parks in Taiwan: Using Q method to identify the performers' subjectivities. Tour. Manag. 2014, 42, 294-304. [CrossRef]

25. Lee, J.H.; Choi, H.O. Stakeholders' views on reducing financial support in governmentled ecotourism areas. Ocean Coast. Manag. 2017, 144, 7-15. [CrossRef]

26. Weaber, D. The Encyclopedia of Ecotourism; Centre for Agriculture and Biosciences International (CABI): Oxford, UK, 2001.

27. Lee, J.H.; Kim, S.H.; Kwon, H.S. Mapping Interests by Stakeholders' Subjectivities toward Ecotourism Resources: The Case of Seocheon-Gun, Korea. Sustainability 2017, 9, 93. [CrossRef]

28. Pasape, L.; Anderson, W.; Lindi, G. Towards Sustainable Ecotourism through Stakeholder Collaborations in Tanzania. J. Tour. Res. Hosp. 2013, 2. [CrossRef]

29. Foucat, V.S.A. Community-based ecotourism management moving towards sustainability, in Ventanilla, Oaxaca, Mexico. Ocean Coast. Manag. 2002, 45, 511-529. [CrossRef]

30. Saguye, T.S. Empirical Analysis of The Reality of Gender Inclusiveness of Participatory Forest Management Model. Am. J. Hum. Ecol. 2016, 5, 36-51.

31. Kontogeorgopoulos, N. Community-Based Ecotourism in Phuket and Ao Phangnga, Thailand. Partial Victor. Bittersweet Rem. 2010, 13, 4-23.

32. Barbosa-Polanco, S.; Molina, D.; Escalona-Segura, G.; Bello, E. Organization and ecotourism in ejidos of the Mexican southeast region. Rev. Estud. Agrar. 2010, 44, 141-160. (In Spanish)

33. Coria, J.; Calfucura, E. Ecotourism and the development of indigenous communities: The good, the bad, and the ugly. Ecol. Econ. 2012, 73, 47-55. [CrossRef]

34. Reimer, J.K.; Walter, P. How do you know it when you see it? Community-based ecotourism in the Cardamom Mountains of southwestern Cambodia. Tour. Manag. 2013, 34, 122-132. [CrossRef]

35. Adhikary, M. Integration of Gender in Agriculture: An Analysis of Situation; Draft Report Summited to Food and Agriculture Organization; Food and Agriculture Organization: Pulchowk, Nepal, 2010; p. 41.

36. Suttie, D.; Vargas-Lundius, R. Migration and transformative pathways: A rural perspective; IFAD Research Series; International Fund for Agricultural Development (IFAD), Ed.; International Fund for Agricultural Development (IFAD): Rome, Italy, 2016; p. 33.

37. World Bank. World Feminization of Agriculture in the Context of Rural Transformations: What Is the Evidence? World Bank: New York, NY, USA, 2016.

38. De Schutter, $\mathrm{O}$. The agrarian transition and the 'feminization' of agriculture Conference paper for discussion. In Proceedings of the Food Sovereignty: A Critical Dialogue International Conference, New Haven, CT, USA, 14-15 September 2013.

39. Kingdon, G.G.; Knight, J. Subjective well-being poverty vs. income poverty and capabilities poverty? J. Dev. Stud. 2006, 42, 1199-1224. [CrossRef]

40. Marcinek, A.; Hunt, C. Social capital, ecotourism, and empowerment in Shiripuno, Ecuador. Int. J. Tour. Anthropol. 2015, 4, 327-342. [CrossRef]

41. Laoire, C.N. Young farmers, masculinities and change in rural Ireland. Irish Geogr. 2002, 35, 16-27. [CrossRef]

42. Charlton, D.; Taylor, J.E. Mexicans Are Leaving Farm Work: What Does It Mean for US Agriculture and Immigration Policy? Agric. Resour. Econ. 2013, 16, 1-4.

43. Steg, L.; Bolderdijk, J.W.; Keizer, K.; Perlaviciute, G. An integrated framework for encouraging pro-environmental behaviour: The role of values, situational factors and goals. J. Environ. Psychol. 2014, 38, 104-115. [CrossRef]

44. Hicks, C.C.; Levine, A.; Agrawal, A.; Basurto, X.; Breslow, S.J.; Carothers, C.; Charnley, S.; Coulthard, S.; Dolsak, N.; Donatuto, J.; et al. Engage key social concepts for sustainability. Science 2016, 352, 38-40. [CrossRef] [PubMed]

45. Clarke, A.H. Understanding sustainable development in the context of emergent environmental perspectives. Policy Sci. 2002, 35, 69-90. [CrossRef]

46. Cross, R.M. Exploring attitudes: The case for Q methodology. Health Educ. Res. 2005, 20, 206-2013. [CrossRef] [PubMed]

47. Brown, S.R. On the radio of Q sort to statements. Operant Subj. 1986, 9, 96-98.

48. Webler, T.; Danielson, S.; Tuler, S. Using Q Method to Reveal Social Perspectives in Environmental Research; Social and Environmental Research Institute: Greenfield, MA, USA, 2009. 
49. Bruce, B.F.; McKeown, T.D. Q Methodology; Quantitative Applications in the Social Science Series/Number 07-066; SAGE Publications: London, UK, 1988.

50. Van Exel, N.J.A.; de Graff, G. Q Methodology: A Sneak Preview. Available online: www.jobvanexel.nl (accessed on 15 November 2016).

51. Steelman, T.A.; Maguire, L.A. Understanding participant perspectives: $Q$ methodology in national forest management. J. Policy Anal. Manag. 1999, 18, 361-388. [CrossRef]

52. Hooker, A.M. Beliefs regarding society and nature: A framework for listening in forest and environmental policy. Operant Subj. 2001, 24, 159-182.

53. Hunt, C.; Stronza, A. Missing the Forest for the Trees? Incongruous Local Perspectives on Ecotourism in Nicaragua Converge on Ethical Issues. Hum. Organ. 2011, 70, 376-386. [CrossRef]

54. Smith, G. Deliberative Democracy and the Environment; Routledge: London, UK, 2003.

55. Saxena, G.; Clark, G.; Oliver, T.; Ilbery, B. Conceptualizing integrated rural tourism. Tour. Geogr. 2007, 9, 347-370. [CrossRef]

56. Slavchevska, V.; Kaaria, S.; Taivalmaa, S.-L. Feminization of Agriculture in the Context of Rural Transformations; World Bank: Washington, DC, USA, 2016.

57. Couturier, P.; Concheiro, L. La Feminización del Campo y sus Impactos Territoriales; UAM-CSH: Ciudad de México, Mexico, 2010; Volume 1.

58. Wang, X.; Wang, X.; Wu, J.; Zhao, G. Social Network Analysis of Actors in Rural Development: A Case Study of Yanhe Village, Hubei Province, China. Growth Chang. 2017. [CrossRef]

59. Polo, A.I.; Frías, D. Collective Strategies for Rural Tourism: The experience of networks in Spain. J. Tour. Consum. Pract. 2010, 2, 25-44.

60. Garrod, B.; Wornell, R.; R. Youell, R. Re-conceptualising rural resources as countryside capital: The case of rural tourism. J. Rural Stud. 2006, 22, 117-128. [CrossRef]

61. Dávid, L. Tourism ecology: Towards the responsible, sustainable tourism future. Worldw. Hosp. Tour. Themes 2011, 3, 210-216.

(C) 2017 by the authors. Licensee MDPI, Basel, Switzerland. This article is an open access article distributed under the terms and conditions of the Creative Commons Attribution (CC BY) license (http://creativecommons.org/licenses/by/4.0/). 